\title{
Hubungan Kadar Hemoglobin Ibu Hamil Trimester Satu dengan Kejadian Stunting pada Balita di Kecamatan Conggeang Kabupaten Sumedang
}

\author{
Muhammad Alstassyura Wiranatagama Aryanto, ${ }^{1}$ Dadi S Argadiredja, ${ }^{2}$ \\ R. Kince Sakinah ${ }^{3}$ \\ ${ }^{1}$ Program Pendidikan Sarjana Kedokteran, Fakultas Kedokteran, Universitas Islam Bandung \\ ${ }^{2}$ Departemen Ilmu Kesehatan Masyarakat, Fakultas Kedokteran, Universitas Islam Bandung \\ ${ }^{3}$ Departemen Ilmu Kesehatan Masyarakat, Fakultas Kedokteran, Universitas Islam Bandung
}

\begin{abstract}
Abstrak
Masa perkembangan anak dimulai saat masih dalam kandungan dan banyak faktor yang dapat memengaruhi perkembangan janin. Anemia pada saat kehamilan sangat berisiko terhadap perkembangan bayi yang akan dilahirkan yang dapat menyebabkan anak mengalami stunting pada balita. Penelitian ini bertujuan mengetahui hubungan kadar hemoglobin ibu hamil trimester satu dengan kejadian stunting pada balita di Kecamatan Conggeang Kabupaten Sumedang pda Desember 2018-Juni 2019. Desain penelitian, yaitu analitik observasional dengan pendekatan case control. Subjek penelitian ini 67 anak dengan kondisi stunting. Teknik pengambilan sampel yang digunakan simple random sampling dengan jumlah 50 balita stunting dan 50 balita normal sebagai kontrol (1:1). Analisis data menggunakan uji chi square dengan $\alpha=0,05$. Hasil penelitian menunjukkan bahwa dari 54 orang ibu hamil dengan anemia yang terdiri atas 25 orang (25\%) anaknya normal dan 29 orang (29\%) anaknya stunting. Sementara 46 orang ibu hamil dengan Hb normal yang terdiri atas 25 orang (25\%) anaknya normal dan 21 orang (21\%) anaknya mengalami stunting. Berdasar atas uji hubungan dengan uji chi square nilai $\mathrm{p}=0,547$. Simpulan, tidak terdapat hubungan antara kadar haemoglobin ibu hamil trimester satu dan kejadian stunting pada balita di Kecamatan Conggeang Kabupaten Sumedang.
\end{abstract}

Kata kunci: Balita, hemoglobin ibu hamil, stunting, trimester satu

\section{The Relation of Haemoglobin Level on the First Trimester Pregnancy with Stunting Incidence Among Toddlers in Conggeang Sub-District, Sumedang District}

\begin{abstract}
The development period of the child begins in the womb. There are many factors could affect fetus development, including haemoglobin of the mother. Anemia during pregnancy is very risky for the fetus development and could cause children under five years to experience stunting. The purpose of this study was to find relation of haemoglobin level in first trimester of pregnant woman with the stunting incidence in Conggeang Sub-district, Sumdeang District during December 2018-June 2019. The study design was observasional analytic with case control approach. The subject of this study is 67 children with stunting. The sampling technique used simple random sampling with total 50 stunted children and 50 normal children as control group (1:1). Data analysis used chi square test with $\alpha=0.05$. The result of this study shows that 54 pregnant woman with anemia, $25(25.0 \%)$ of them have children with normal condition and $29(29.0 \%)$ have stunted children. Based on chi square test $(\mathrm{p}=0.547)$, there was no relation between haemoglobin level in first trimester of pregnant woman with stunting incidence in Conggeang Sub-district, Sumedang District. In conclusion, there is no relation beetween haemoglobin level in first trimester of pregnant woman and stunting incidence in Congeang Sub-District in Sumedang District.
\end{abstract}

Keywords: First trimester, hemoglobin for pregnant women, stunting, toddler

Korespondensi: Muhammad Alstassyura Wiranatagama Aryanto, Program Studi Pendidikan Sarjana Kedokteran, Fakultas Kedokteran, Universitas Islam Bandung, Jalan Taman Sari No. 2, Kota Bandung, Provinsi Jawa Barat. Telepon: (022) 4203368 Faksimile: (022) 4231213 HP: 081288908610 


\section{Pendahuluan}

Stunting merupakan kondisi anak panjang atau tinggi badan berdasar atas usia menurut standar WHOMGRS (World Health Organization) (Multicentre Growth Reference Study) dengan z-score -2 SD atau disebut pendek, sedangkan jika panjang atau tinggi badan berdasar atas usia menurut standar WHOMGRS dengan z-score -3 SD dinyatakan sangat pendek. Kondisi stunting mengakibatkan penurunan kecepatan pertumbuhan akibat ketidakseimbangan gizi. Stunting akan menyebabkan dampak jangka panjang yang akan tergangunya perkembangan fisik, mental intelektual, serta kemampuan kognitif. ${ }^{1}$

Berdasar atas Riset Kesehatan Dasar (RISKESDAS) tahun 2018 di Indonesia, angka stunting masih cukup tinggi, yaitu 30,8\% pada tahun 2018 untuk balita (bawah lima tahun), dengan pembagian sangat pendek $11,5 \%$ dan pendek 19,3\%, sedangkan untuk baduta (bawah dua tahun) 29,9\% pada tahun 2018 dengan pembagian sangat pendek $17,1 \%$ dan pendek mencapai 12,8\%. Di Jawa Barat mencapai angka 31,0\% pada tahun 2018 untuk balita dan baduta mencapai 28,0\%. ${ }^{2}$ Dari salah satu kabupaten yang terdapat di Jawa Barat, yaitu di Kabupaten Sumedang angka kejadian stunting sangat tinggi mencapai angka $41,08 \%$ pada tahun 2018. ${ }^{3,4}$

Anemia dalam kehamilan adalah haemoglobin dalam darah kurang dari $11 \mathrm{~g} / \mathrm{dL}$ pada trimester I dan III atau kadar $<10,5 \mathrm{~g} / \mathrm{dL}$ pada trimester II. Di Indonesia, anemia pada ibu hamil cukup tinggi. Berdasar atas Riskesdas tahun 2013 ibu hamil dengan anemia mencapai 37,1\%, sedangkan di tahun 2018 angka lebih tinggi mencapai $48,9 \% .^{3}$

Penelitian yang telah dilakukan mengungkapkan salah satu faktor penting yang dapat menyebabkan anak stunting di antaranya adalah hambatan pertumbuhan ketika anak di dalam kandungan ibu. Asupan zat gizi ibu yang tidak mencukupi untuk mendukung pertumbuhan dan perkembangan atau kondisi ibu yang mengalami kekurangan energi kronik (KEK) sehingga proses pertumbuhan dan tumbuh kembang janin menjadi terhambat. Dalam hasil penelitiannya, ibu hamil dengan keadaan KEK merupakan penyebab 25-30\% intrauterine growth retardation (IUGR) yang jika dibiarkan akan menyebabkan anak lahir BBLR sehingga berisiko mengalami stunting di masa yang akan datang. ${ }^{5}$

Di Indonesia dan di Jawa Barat khususnya daerah Kabupaten Sumedang angka stunting masih terbilang tinggi dengan angka 41,08\%. Salah satu kecamatan yang ada di Kabupaten Sumedang, yaitu Kecamatan Conggeang menurut laporan dari Puskesmas Conggeang terdapat 67 balita stunting atau empat persen (4\%) yang tersebar di 12 desa, dan yang terbesar prevalensinya terdapat di Desa Ungkal, yaitu mencapai empat puluh pesen (40\%) anak mengalami stunting. Melihat data tersebut tentunya termasuk cukup tinggi sehingga masih sangat perlu ada perhatian dan penangan khusus terhadap hal tersebut. Berdasar atas fenomena tersebut maka penelitian ini bertujuan mengetahui hubungan kadar haemoglobin rendah pada ibu hamil dengan anak stunting di Kabupaten Sumedang, Kecamatan Conggeang.

\section{Metode}

Penelitian ini adalah penelitian analitik observasional dengan menggunakan pendekatan kasus kontrol. Pemilihan sampel dalam penelitian ini dipilih berdasar atas kriteria inklusi yang telah ditentukan dan menggunakan teknik simple random sampling. Kriteria inklusi penelitian ini meliputi ibu yang memiliki anak usia kurang dari lima tahun yang mengalami stunting yang terdaftar di Puskesmas UPT Conggeang Kabupaten Sumedang dan ibu yang diperiksa kadar hemoglobin saat kehamilan trimester satu. Kriteria eksklusi penelitian ini meliputi ibu yang memiliki rekam medis tidak lengkap.

Tempat penelitian dilakukan di Puskesmas UPT Conggeang, Kabupaten Sumedang dari bulan Desember 2018 hingga Juni 2019. Analisis data menggunakan analisis univariat dan bivariat. Aspek etik pada penelitian ini mengenai kerahasiaan data rekam medis pasien Puskesmas UPT Conggeang, Kabupaten Sumedang. Etik ini telah disetujui oleh Komite Etik Fakultas Kedokteran Universitas Islam Bandung dalam surat Nomor 027/Komite Etik.FK/ $\mathrm{IV} / 2019$.

\section{Hasil}

Penelitian ini mendapatkan 67 anak mengalami stunting dari 1.675 anak yang diperiksa. Berikut merupakan gambaran mengenai kadar hemoglobin ibu hamil di wilayah kerja Puskesmas UPT Conggeang Kabupaten Sumedang.

Tabel 1 Deskriptif Mengenai Kadar Hemoglobin Ibu Hamil Trimester Satu

\begin{tabular}{ccc}
\hline Kadar HB & $\begin{array}{c}\text { Frekuensi } \\
(\mathbf{n = 1 0 0 )}\end{array}$ & Persentase \\
\hline Normal & 46 & 46 \\
Anemia & 54 & 54 \\
\hline
\end{tabular}

Keterangan Hb normal: $>11$ g/dL, anemia $<11$ g/dL

Berdasar atas Tabel 1 mengenai kadar hemoglobin ibu hamil, didapatkan hasil bahwa yang berada pada keadaan normal sebanyak 46 orang (46\%), sementara anemia sebanyak 54 orang (54\%).

Berdasar atas hasil pengolahan data dari 50 anak stunting dan 50 anak normal sebagai kontrol dilihat hubungan hemoglobin ibu ketika hamil maka diperoleh hasil hubungan antara variabel independen (kadar hemoglobin ibu hamil) dengan variabel dependen (kejadian stunting) sebagai berikut:

Tabel 2 Hubungan Kadar Hemoglobin Ibu Hamil Trimester Satu dengan Kejadian Balita Stunting

\begin{tabular}{cccccc}
\hline $\begin{array}{c}\text { Kadar } \\
\text { Hb saat } \\
\text { Ibu }\end{array}$ & Normal & Stunting & Jumlah & $\mathbf{X}^{2}$ & $\begin{array}{c}\text { Nilai } \\
\mathbf{p}\end{array}$ \\
Hamil & $\mathbf{n}$ & $\mathbf{n}$ & $\mathbf{n}$ & & \\
\hline Anemia & 25 & 29 & 54 & 0,644 & 0,574 \\
Normal & 25 & 21 & 46 & & \\
\hline
\end{tabular}


Berdasar atas Tabel 2 kadar hemoglobin saat ibu hamil kategori anemia sebanyak 54 orang (54\%) yang terdiri atas 25 orang (25\%) normal dan 29 orang (29\%) stunting, Ibu hamil dengan $\mathrm{Hb}$ normal sebanyak 46 orang (46\%) yang terdiri atas 25 orang (25\%) normal dan 21 orang (21\%) berada pada kejadian stunting.

Berdasar atas hasil uji hubungan dengan uji chi squre didapatkan hasil Pearson chi squre sebesar o,644 dengan signifikansi sebesar 0,547, dikarenakan signifikansi sebesar 0,547>0,05 maka dapat dinyatakan tidak terdapat hubungan antara kadar hemoglobin ibu hamil trimester satu dan kejadian stunting pada balita di Kecamatan Conggeang Kabupaten Sumedang.

Responden dalam peneltian ini adalah 50 anak stunting dan 50 anak normal sebagai kontrol yang dilihat riwayat kadar hemoglobin ibu saat hamil trimester satu di wilayah kerja Puskesmas UPT Conggeang Kabupaten Sumedang tahun 2018, berikut hasil identitas responden berdasar atas usia anak, status gizi, berat badan, dan alamat asal. sebagai berikut:

Tabel 3 Deskriptif Mengenai Jenis Kelamin dan Berat Badan

\begin{tabular}{llcc}
\hline $\begin{array}{l}\text { Jenis } \\
\text { Kelamin dan } \\
\text { Berat Badan }\end{array}$ & & $\begin{array}{c}\text { Frekuensi } \\
(\mathbf{n}=50)\end{array}$ & $\begin{array}{c}\text { Persentase } \\
\text { (\%) }\end{array}$ \\
\hline Jenis kelamin & Laki-Laki & 24 & 48 \\
& Perempuan & 26 & 52 \\
Kondisi badan & Sangat kurus & 2 & 4 \\
& Kurus & 19 & 38 \\
& Normal & 29 & 58 \\
& Gemuk & 0 & 0 \\
\hline
\end{tabular}

Berdasar atas Tabel 3 mengenai jenis kelamin dan kondisi berat badan didapatkan hasil laki-laki sebanyak 24 orang (48\%), sementara perempuan sebanyak 26 orang (52\%). Kondisi badan sangat kurus pada 2 orang (4\%), kurus 19 orang (38\%), normal 29 orang (58\%), dan tidak ada yang gemuk.

\section{Pembahasan}

Berdasar atas hasil penelitian dari 100 ibu yang diteliti, sebagian besar ibu mengalami anemia atau kadar hemoglobin rendah sebanyak 54 orang (54\%). Untuk mengetahui status hemoglobin ibu hamil, ibu diperiksa kadar hemoglobin ketika usia kandungan trimester satu. Berdasar atas Peraturan Menteri Kesehatan Republik Indonesia Nomor 25 Tahun 2015 tentang Penyelenggaraan Pemeriksaan Laboratorium untuk Ibu Hamil, Bersalin, dan Nifas di Fasilitas Pelayanan Kesehatan dan Jejaring Pelayanannya meliputi pemeriksaan rutin hemoglobin saat kehamilan. ${ }^{6}$

Kadar hemoglobin ibu saat hamil trimester satu dikategorikan menjadi anemia dan normal. Kadar hemoglobin pada ibu hamil sangat penting bagi janin yang dikandung maupun ibunya itu sendiri. Kadar hemoglobin rendah (anemia) dapat memudahkan infeksi, perdarahan antepartum, abortus, ketuban pecah dini, hambatan tumbuh kembang janin dalam rahim, dan pengeluaran ASI berkurang. ${ }^{7}$ Penelitian ini, jumlah ibu anemia hamil trimester satu lebih banyak dibanding dengan ibu hamil hemoglobin normal. Hal ini sejalan dengan penelitian yang dilakukan oleh Kawengian dan Mayulu 7 di Puskesmas Lolak menyatakan bahwa dari 51 responden, sebagian besar responden (94\%) mengalami anemia dan hanya 3 responden (6\%) yang tidak menderita anemia. ${ }^{8}$

Masa lima tahun pertama kehidupan anak sering ditandai dengan pertumbuhan dan perkembangan yang pesat. Pada masa tersebut pertumbuhan yang terjadi lebih cepat dibanding dengan periode lainnya dan memerlukan jumlah zat gizi yang lebih banyak. ${ }^{9}$ Namun, di Indonesia pada saat periode tersebut sering kali mengalami gangguan yang dapat menghambat pertumbuhan dan perkembangan. Berdasar atas hasil penelitian di wilayah kerja Puskesmas Conggeang terdapat 67 anak mengalami stunting. Namun, dalam penelitian ini hanya diambil anak yang mengalami stunting (kasus) sebanyak 50 balita (50\%). Dengan jumlah tersebut kejadian stunting di daerah Puskesmas Conggeang tidak sedikit dan akan berdampak buruk bagi balita. Beberapa dampak dari stunting di antaranya kognitif lemah, psikomotorik terhambat, dan kemampuan kognisi serta intelektual yang kurang baik. Hal tersebut dapat menyebabkan balita lebih sulit untuk menguasai ilmu pengetahuan, sulit mendapatkan prestasi dalam olahraga, lebih mudah mendapatkan penyakit degeneratif, serta kualitas sumber daya manusia suatu bangsa dapat menurun. ${ }^{10}$

Penelitian ini bertentangan dengan penelitian Widyaningrum dan Dhiyah ${ }^{10}$ di Madiun yang mengungkapkan terdapat hubungan riwayat anemia kehamilan dengan kejadian stunting pada balita. Penelitian tersebut berbeda dengan penelitian ini yang juga mencari hubungan haemoglobin ibu hamil trimester satu dengan kejadian stunting pada balita. Namun, pada penelitian lainnya oleh Ruaida ${ }^{11}$ tentang hubungan antara anemia ibu hamil dan kejadian stunting pada anak usia 6-24 bulan di Kota Yogyakarta memberikan hasil yang sama, tidak terdapat hubungan antara ibu yang mengalami anemia dan kejadian stunting.

Meskipun penelitian ini tidak memiliki hubungan, namun jumlah ibu hamil yang mengalami anemia pada penelitian ini lebih banyak, yaitu 54 orang (54\%) dibanding dengan ibu yang tidak mengalami anemia 46 orang (46\%). Ibu yang mengalami anemia saat kehamilan akan meningkatkan peluang memiliki anak yang stunting sebanyak 1,36 kali lebih tinggi dibanding dengan ibu yang tidak mengalami anemina. ${ }^{12}$ Tentunya penelitian ini dapat menjadi bahan intervensi untuk pelayanan kesehatan terkait, kepada ibu yang mengalami anemia pada trimester satu agar dapat diberikan suplemen zat besi. Ibu diberikan pola makan yang baik dan diberikan suplemen zat besi sesuai dengan standar pelayanan antenatal care, yaitu 90 tablet selama kehamilan sehingga dapat memberikan pengaruh yang sangat bermakna pada status $\mathrm{Hb}$ ibu hamil yang awal mengalami anemia menjadi tidak anemia lagi. ${ }^{13}$ 


\section{Simpulan}

Hasil penelitian ini menunjukkan bahwa tidak terdapat hubungan kadar haemoglobin ibu hamil trimester satu dengan kejadian stunting pada balita di Kecamatan Conggeang Kabupaten Sumedang.

\section{Ucapan Terima Kasih}

Ucapan terima kasih kepada seluruh ibu yang mempunyai balita di Kecamatan Congeang Kabupaten Sumedang yang turut serta dalam penelitian.

\section{Daftar Pustaka}

1. Losong NHF, Adriani M. Perbedaan kadar hemoglobin, asupan zat besi, dan zinc pada balita stunting dan non stunting the differences of hemoglobin level, iron, and zinc intake in stunting and non stunting toodler. Amerta Nutr. 2017;1(2):117-23.

2. FAO. SOFI 2018 - The state of food security and nutrition in the world. Global Food Insecurity Report. Rome. FAO, SOFI; 2018.

3. Ministry RH. Hasil utama Riskesdas 2018. Jakarta: Kementeri Kesehatan Badan Penelitian dan Pengembangan Kesehatan; 2018.

4. Humas Sekda Kabupaten Sumedang. 10 desa stunting di Sumedang, akan diintervensi. Sekr Drh Kabupaten Sumedang. 2018 April:9-10.

5. Swathma D, Lestari H, Teguh R. Analisis faktor risiko bblr, panjang badan bayi saat lahir dan riwayat imunisasi dasar terhadap kejadian stunting pada balita usia 12-36 bulan di wilayah kerja Puskesmas Kandai Kota Kendari 2016. JIM Kesmas. 2016;1(3):1-10.

6. Astriana W. Kejadian anemia pada ibu hamil ditinjau dari paritas dan usia. J Aisyah J Ilmu Kesehat. 2017;2(2):123-30.

7. Kawengian SE, Mayulu N. Faktor-faktor yang berhubungan dengan kadar hemoglobin pada ibu hamil di Puskesmas Lolak. J e- Biomedik. 2017;5.

8. Lareini Yuli, Sofiyatin Reni RY. Hubungan tingkat pengetahuan sikap dan perilaku ibu terhadap konsumsi zat gizi (energi, protein) pada balita gizi kurang di Desa Labuhan Lombok. J Chem Inf Model. 2015;53(9):1689-99.

9. Dasman H. Empat dampak stunting bagi anak dan negara Indonesia Empat dampak stunting bagi anak dan negara Indonesia. [diunduh $5 \mathrm{Mei}$ 2019]. Tersedia dari: https://theconversation.com/ empat-dampak-stunting-bagi-anak-dan-negaraindonesia-110104

10. Widyaningrum DA, Dhiyah AR. Riwayat anemia kehamilan dengan kejadian stunting pada balita di Desa Ketandan Dagangan Madiun. Medica Majapahit. 2018;10(2):86-99.

11. Ruaida N. Hubungan anemia ibu hamil dengan kejadian stunting pada anak usia 6-24 bulan di Kota Yogyakarta. [diunduh 15 Mei 2019]. Tersedia dari: http://etd.repository.ugm.ac.id/penelitian/ detail/66908

12. Octaviani I, Makalew L, Sesca SD. Profil haemoglobin pada ibu hamil dilihat dari beberapa faktor pendukung. JIDAN. 2016;4(1):22-30. 